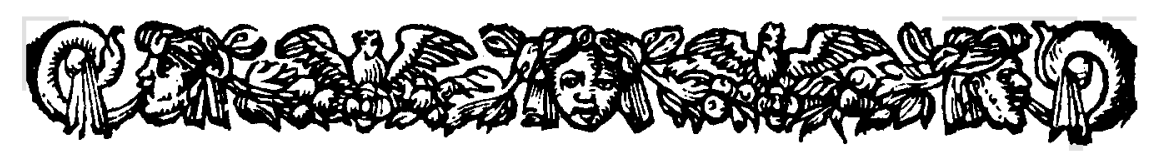

\author{
JOHN R. KNOTT, JR.

\section{Bunyan's Gospel Day: A Reading of The Pilgrim's Progress}

ECENTLY Stanley Fish has argued that The Pilgrim's Progress
offers only an illusory kind of progress and that it is in fact "anti-
progressive, both as a narrative and as a reading experience."1 The linear form of the work constitutes a danger for the reader, according to Fish, because it "spatializes and trivializes" the "way" of Christ's "I am the way." As Fish demonstrates, Bunyan discredits the assumption of various pilgrims that all they must do to reach the New Jerusalem is to follow an external, readily discernible way. Formal and Hypocrisy err in assuming that they are in the same way of faith that Christian is ("what's matter

1. In Self-Consuming Artifacts (Berkeley and Los Angeles, 1972), chap. Iv, "Progress in The Pilgrim's Progress," pp. 224-64, a slightly expanded version of an article that appeared in $E L R, 1$ (1971), 261-93. My argument implicitly questions two assumptions upon which Fish's claim that The Pilgrim's Progress is a "self-consuming artifact" depends. The first is that Bunyan continually frustrates expectations aroused in the reader by the linear form of his work and hence disqualifies the work "as a vehicle of the insight it pretends to convey" (p. 225). This position depends upon the unstated assumption that Bunyan was interested only in exposing his reader's limitations. To maintain it Fish must ignore Bunyan's climactic celebration of the joys of Beulah and of the New Jerusalem and the various signs that point to these joys along the course of Christian's journey. The other major assumption that I mean to question is that "in The Pilgrim's Progress there is an inverse relationship between visibility and reliability" (p. 240). This depends upon the further assumption that all Christian's experiences should be regarded as occurring in the "carnal" world in which Christians must learn to distrust the evidence of their senses. Such assumptions will work for Vanity Fair but not for the Delectable Mountains or for Beulah, landscapes from which Christian derives sensuous enjoyment that is a sign of spiritual progress. Some of what I have to say, particularly about the subjectivity of the individual way of faith, complements Fish's discussion, but where he looks to a tension between normal habits of perception and the demands of faith to explain the dynamics of the work I look primarily to Bunyan's understanding and use of his source, the Bible. 
which way we get in; if we are in, we are in" 2 ), as do others such as Atheist and Ignorant that Christian encounters at various points in his journey. But one can note this aspect of The Pilgrim's Progress without concluding that it compromises the basic figure of the journey which underlies the narrative. What Fish pictures as deceptive linear form was the sustaining metaphor of Puritan spiritual life in Bunyan's time. To devalue this metaphor by considering it in purely formal terms is to explain away the reason for the extraordinary power of The Pilgrim's Progress over the imaginations of actual readers for several centuries.

Both the Apology to The Pilgrim's Progress and the verse Conclusion are remarkable for Bunyan's preoccupation with justifying his figurative method to skeptical Puritan readers, whom he imagines objecting, "Metaphors make us blind." Bunyan defends his form by pointing to the substance it contains, as in the comparison of his work with a cabinet offered in the Apology ("Mydark and cloudy words they do but hold / The Truth as Cabinets inclose the Gold" [p. 4]), but he does not thereby imply that the form is an inadequate means of expressing his message. I would argue, with U. Milo Kaufmann, that Bunyan was in truth uncomfortable with the Puritan habit of reducing biblical metaphor to doctrine. ${ }^{3}$ The very fact that Bunyan protests so much in attempting to justify his method reveals the depth of his commitment to "similitude" as a means of expressing God's truth. Some of his formulations actually tend to undermine the conventional distinction between kernel and husk. In the conclusion, for example, he suggests that the reader might not be able to "extract" his gold from the ore in which it is wrapped and chides: "None throws away the Apple for the Core" (p. 164).

Bunyan's most significant appeals are to scriptural authority, and underlying these appeals is a conviction about the metaphoric nature of much Biblical truth. Bunyan saw that the prophets "used much by Metaphors / To set forth Truth" (p. S) because God's truth could best be comprehended figuratively. He never suggests a separation between the "Types, Shadows, and Metaphors" of the Bible and the truth that they express. For Bunyan the light of the Gospel "springs" from its "Dark Figures." He felt that by

2. John Bunyan, The Pilgrim's Progress, J. B. Wharey, ed., 2nd ed. rev. by Roger Sharrock (Oxford, 1960), p. 40. Quotations from The Pilgrim's Progress are taken from this edition.

3. In "The Pilgrim's Progress" and Traditions in Puritan Meditation (New Haven, 1966). See especially pp. 3-15. Kaufmann suggests that Bunyan's efforts to prove that his metaphors are unambiguous (logos) arise from a need to satisfy the expectations of his audience and finds that other aspects of his Apology, especially the concluding lines, reveal a sense of his narrative as $m y$ thos, appealing to his audience in non-rational ways. My intention is to extend Kaufmann's argument, though without using his terms. 
employing a similarly "dark" method he could make truth "cast forth its rayes as light as day" (p. 6). Such language does not suggest a concern with doctrine and uses (though Bunyan was of course concerned with showing his readers how to conform their lives to God's truth) but with conveying the kind of joyful illumination that he found in Scripture. He would make "The Blind... delightful things to see" (p. 7).

To appreciate the nature of Bunyan's commitment to the metaphor of the way one must recognize that he used this metaphor in two basic senses, both of which are important. His genius for exploiting the dramatic potential of biblical metaphor is perhaps most apparent from his success at holding in suspension these two senses of his central figure. The way is the path of all Christians through the wilderness of the world, the way "From This World To That Which Is To Come," and simultaneously the inner way of faith of the individual believer. Without a strong conviction about where the way leads the pilgrim would never set out at all, yet he cannot arrive at the promised end unless he understands how to walk.

Bunyan talks about the second sense of his metaphor, what it means to walk in the way of faith, in The Holy City, his commentary on Revelation. He explains: ". . . it is usual in the Holy Scripture to call the transformation of the sinner from Satan to God a holy way, and also to admonish him that is so transformed to walk in that way, saying, Walk in the faith, love, spirit, and newness of life, and walk in the truth, ways, statutes, and judgments of God." 4 Here and in The Pilgrim's Progress Bunyan draws upon the Old Testament sense of walking in the "way of the righteous" (Psalm 1.6), in the "truth" of God, as well as upon the New Testament sense of walking "in the Spirit" (Gal. 5.16) and "in newness of life" (Rom. 6.4), but of course the New Testament meaning is primary. Faith must be attested by a genuine "newness of life."

This sense of the way as determined by the faith of the individual pilgrim coexists with the other sense of the way as a common journey of all the faithful from the City of Destruction to the New Jerusalem. The design of The Pilgrim's Progress, and much of its force, depends upon the figurative reading of the experience of the Israelites that Bunyan and countless other Puritans learned from Hebrews. ${ }^{5}$ The Heavenly Footman shows more ex-

4. The Works of John Bunyan, ed. George Offor (Glasgow, 1859), III, 437. Hereafter cited as Works.

5. See Brainerd Stranahan, "Bunyan and the Bible: Uses of Biblical Materials in the Imaginative Structure of The Pilgrim's Progress," diss., Harvard, 1965, for a very full discussion of Bunyan's biblical sources. Stranahan notes the high frequency of references to Hebrews in The Pilgrim's Progress and Grace Abounding. 
plicitly than its successor, The Pilgrim's Progress, the centrality of the figure of the journey to Bunyan's understanding of the Christian life: "Because the way is long (I speak metaphorically) and there is many a dirty step, many a high hill, much work to do, a wicked heart, world, and devil, to overcome; I say, there are many steps to be taken by those that intend to be saved, by running or walking, in the steps of that faith of our father Abraham. Out of Egypt thou must go through the Red Sea; thou must run a long and tedious journey, through the vast howling wilderness, before thou come to the land of promise."6 Bunyan saw that he did not speak any less truly for speaking "metaphorically." The metaphor, which he saw as embodying God's promise that his saints would succeed in making their way through the wilderness to the "land of promise," is the key to his conception of The Pilgrim's Progress and to the appeal of the work for his Puritan readers. His "dream" could succeed because the habit of thinking of the world metaphorically, as a wilderness to be journeyed through, was ingrained in his readers, and because they could identify readily with someone who could show them what it meant to follow "in the steps of that faith of our father Abraham."7 The ground of their faith was a belief in the possibility of progress from this world to the next, and Bunyan's work offered them the hope that an ordinary believer, not without weaknesses, might attain the New Jerusalem.

The encounter of Christian and Hopeful with the shepherds of the Delectable Mountains provides a revealing illustration of Bunyan's ability to combine the two basic senses of the metaphor of the way. This episode offers one of the best examples in The Pilgrim's Progress of the subjectivity of the individual way of faith:

6. Works, III, 382.

7. Such readers would have seen references linking the pilgrims with the saving history of the Israelites as putting the authority of the Word behind the metaphor of the journey. The Shining Ones confirm Christian's identity as a spiritual descendant of Abraham when they prepare him for entering the New Jerusalem: "You are going to Abraham, to Isaac, and Jacob, and to the Prophets" (p. 159). Secret tells Christiana before she sets out that God "will feed thee with the Fat of his House, and with the Heritage of Jacob thy Father" (p. 179). Christian interprets his journey in the light of Old Testament history, identifying himself as "of the Race of Japhet, whom God will perswade to dwell in the Tents of Shem" (p. 46), thereby associating himself with the favored line that will have dominion over Canaan according to God's promise to Noah in Genesis 9.27. When he loses his roll, he recalls the trials of the Israelites: "Thus it happened to Israel for their sin, they were sent back again by the way of the Red-Sea" (p. 44). Bunyan again invokes the Exodus in Part II when he describes the seal with which Interpreter marks the children of Christiana as "the contents and sum of the Passover which the Children of Israel did eat when they came out from the Land of Egypt" (p. 208). 
Chr. Is this the way to the Coelestial City?

Shep. You are just in your way.

Chr. How far is it thither?

Shep. Too far for any, but those that shall get thither indeed.

Chr. Is the way safe, or dangerous?

Shep. Safe for those for whom it is to be safe, but transgressors shall fall therein. (p. 119)

The deliberate ambiguity forces one to recognize that the nature of the way - -its length and the specific dangers to be encountered-depends upon the faith of the individual pilgrim. The shepherds can assess the spiritual health of the wayfarers at the moment ("You are just in your way"), but this spiritual condition is dynamic and precarious. To give definite answers to the pilgrims' questions would be to ignore the uncertainty with which faith must live. In The Heavenly Footman Bunyan says, "as the way is long, so the time in which they are to get to the end of it is very uncertain; the time present is the only time." 8 Christian's faith exists only in this "time present," because faith must be renewed continuously.

Alice's encounter with the Cheshire Cat reads as though Carroll might have conceived it as a parody of Bunyan's meeting with the shepherds:

\footnotetext{
"Would you tell me, please, which way I ought to go from here?"

"That depends a good deal on where you want to get to," said the Cat.

"I don't much care where-" said Alice.

"Then it doesn't matter which way you go," said the Cat.

"--so long as I get somewhere," Alice added as an explanation.

"Oh, you're sure to do that," said the Cat, "if you only walk long enough."
}

The Cheshire Cat's responses appear nonsensical only because he does not give Alice the kind of certainty she wants. His logic is impeccable, and it serves as an amusing way of pointing up her confusion. One way is as good as another unless she decides the "ought." She is bound to get "somewhere" if she walks "long enough," but whether she thinks she is "somewhere" will depend upon her expectations. The response of the shepherds to Christian's inquiries has the similar effect of turning the questions back on the questioner, though they can offer no assurances that Christian will get anywhere at all because they are talking about a metaphorical way that depends upon a faith that may collapse at any moment. Carroll's logical cat would find them incomprehensible, and probably silly.

Yet Bunyan's shepherds are also talking about the one true way that leads to the New Jerusalem (and not just "somewhere"), and the Delectable Mountains mark a station along that way, as the Interpreter's House and

8. Works, III, 382.

9. The Annotated Alice, ed. Martin Gardner (New York, 1960), p. 88. 
House Beautiful mark earlier stations. Christian's actions describe a progression through stages of spiritual life. This progression is clearer in some places than in other-notably near the beginning and the end of the journey --but its outlines would have been familiar to readers acquainted with Puritan spiritual autobiography. Together Christian's experiences constitute a "Calvinist soul-history" (to use Sharrock's term ${ }^{10}$ ) proceeding from an initial conviction of sin that lands him in the Slough of Despond to the instruction in Scripture that he receives in the Interpreter's House (where he is exposed to scenes designed to "prick him forward" in the way), and through the various trials of the major part of the journey until he finally arrives at the assurance of God's mercy represented by Beulah.

One should not attach too much significance to the order of the temptations that Christian encounters, yet there is some point to the sequence. The more violent, and dramatic, assaults on Christian's faith come earlythe most violent, that of Apollyon, soon after he has put on the Pauline armor of the soldier of Christ. The transition from the Valley of Humiliation to the Valley of the Shadow of Death makes sense in terms ofChristian's experience; he has just faced the prospect of annihilation in the battle with A pollyon. After escaping the fiends of the Valley of the Shadow, Christian must face the hostile society of Vanity Fair (after an interlude occupied by conversation with Faithful and Talkative). Again the threat is overt and violent, although violence in Vanity Fair is more insidious and contemptible for being sanctioned by social forms. Later Christian encounters more subtle kinds of temptations, involving fraud or deceptive appearances (Demas, By-Path Meadow, Flatterer, the seductive appeal of the Enchanted Ground for the pilgrim nearing the end of his journey).

The Doubting Castle episode proves that Christian can lose the way at a relatively late point in the journey through overconfidence, not that he has failed to grow in faith and understanding. The very intensity of his despair suggests bitter chagrin at having erred so foolishly after having come through so many trials. In Doubting Castle Hopeful appeals to Christian's past victories over Apollyon and the terrors of the Valley of the Shadow ("remembrest thou not how valiant thou hast been heretofore" [p. 116]), but valor will not help him in this very different kind of dilemma. In the first instance he had saved himself by continuing to fight, in the second by continuing to walk. In Doubting Castle Christian is baffled and dismayed by the fact that it seems impossible either to defeat his enemy or to get his

10. Roger Sharrock, John Bunyan: The Pilgrim's Progress (London, 1966), p. 26. See also Kaufmann, pp. 106-17, on the unity of Puritan religious experience. 
key. The brilliance of the episode lies in the fact that Bunyan makes escape seemingly so difficult yet paradoxically so easy; Christian has only to remember that Scripture has provided him with his own key, a solution that comes to him as a result of prayer.

Christian again lapses into doubt at the River of Death, this time a paralyzing "darkness and horror" that causes him to forget temporarily the "sweet refreshments" he had met with in the way and the assurance they had given him of reaching the "Land that flows with Milk and Honey" (p. 157). Bunyan's emphasis upon the "sorrows of death" does not subvert the metaphor of the journey; it merely indicates his acute sense of the dangers of this final obstacle, even for those who have persevered in the way of holiness. Reaching the plane of assurance represented by Beulah does not relieve one of the necessity of making the crossing.

Christian continues to be vulnerable to doubt throughout his pilgrimage because Bunyan believed that faith could never be completely secure in this world. But his doubts are prompted by very different kinds of trials, appropriate to different stages of the journey, and in each case we are reminded of what has gone before. Christiana's journey presents a clearer, less interrupted sense of progress, of course, because her way is so much easier. Giant Despair falls before Great-heart, the last of a succession of giants to suffer such a fate. Christiana receives so much support from her guides and the companies of Christians she encounters that she scarcely has the opportunity to doubt her salvation. After leaving the Delectable Mountains she sings: "Behold, how fitly are the Stages set! / For their Relief, that Pilgrims are become" (p. 289).

My point is simply that one can and should talk about stages in the journey that correspond to mileposts in the development of spiritual vitality. Christiana follows the same way that Christian does, though her temptations differ in degree from his, because Bunyan believed that patterns could be found in Puritan spiritual life. Kaufmann has suggested that Christian "helps to define the road to be walked" and prepares the way for his wife and family; by markers and victories "he transforms the way he covers" without, however, changing its outlines. ${ }^{11}$ One could take Kaufmann's argument a step further and say that by elaborating the metaphor of the way Bunyan ordered and explained the potentially chaotic events of spiritual life for his readers. In describing the Valley of the Shadow of Death and showing Christian passing through it he localized the terrors of death and suggested that they could be overcome.

11. Kaufmann, p. 115. 
To understand the nature of Christian's spiritual progress one must look more closely at the stages of his journey, particularly at his experience in such places as the Delectable Mountains and the land of Beulah. Those episodes that mark Christian's growing awareness of divine favor serve to establish the truth embodied in the biblical metaphor of the journey and hence to convince the reader that the goal for which Christian strives is real. Bunyan's narrative works by establishing the credibility of an entire world of spiritual experience, based upon the Word and opposed to the actual world, the world of his readers' everyday experience in which Christian first appears. But Christian, and the reader, can enter this spiritual country only by recognizing the absoluteness of the claim made by the Word and by stripping themselves of the assumptions that govern life in the secular world. One must first understand the form that this process of disengagement takes in Bunyan's narrative.

Christian's sudden recognition of the force of the biblical truth that the world he inhabits belongs to the City of Destruction propels him into what Bunyan in the Apology calls "our Gospel-day," a time defined by the Word, and in this "Gospel-day," according to a verse from Corinthians that Bunyan quotes in Come and Welcome to Jesus Christ: "Now is the acceptable time, behold now is the day of salvation" (II Cor. 6.2). In the perpetual "time present" of faith it is always "now," and Bunyan's Christian acts out of a sense of urgency that is incomprehensible to anyone who does not recognize the same biblical imperative. Obstinate speaks for the community when he dismisses him as "brain-sick."

Christian's dramatic flight from his family-with his fingers in his cars and crying, "Life, Life, Eternal Life"-appears ludicrous from any perspective other than the biblical one that Bunyan labored to establish. Mark Twain had Huck Finn encounter Bunyan at one point in his journey, when he investigates the books in the Grangerford's library: "One was Pilgrim's Progress, about a man that left his family, it didn't say why. I read considerable in it now and then. The statements was interesting but tough." 12 Huck is an ideal vehicle for Twain's irony. To one schooled in the hard business of survival in the world Christian's way of faith makes no sense at all. Bunyan knew that his message was "tough," and he chose to emphasize its difficulty so that there could be no mistake about the kind of renunciation that following the way demands. To put it another way,

12. Adventures of Huckleberry Finn, ed. E. S. Bradley, R. C. Beatty, and E. H. Long (New York, 1961), p. 83. 
Bunyan knew that biblical truth was "dark" not only because it is often metaphoric but because it is at bottom paradoxical, riddling the exhorts Christiana to expound her "riddles" in the prefatory verses to Part II of The Pilgrim's Progress).

The Gospel demands that one lose his life in order to save it (Mark 8.35) and further that one hate his family in order to follow Christ (Luke 15.26). If one chooses the way of Christ, one will necessarily appear foolish in the eyes of the world. The Pauline opposition between the spirit and the flesh that provided the basis for Augustine's conception of rival cities of God and man lies behind Bunyan's sense of a way that inevitably brings the pilgrim into conflict with the world (one must go "out of the World" to avoid Vanity Fair) and yet leads him beyond it. Bunyan's narrative insists that the claims of the way and those of the world are mutually exclusive. The pilgrim must set his course "against Wind and Tide" (p. 100), as Christian increasingly realizes. Faithful relates that he has learned to ignore the "hectoring spirits of the world" because he recognizes that "what God says, is best, though all the men in the world are against it" (p. 73).

Bunyan's account of his own trial dramatizes as clearly as anything in The Pilgrim's Progress the unavoidable conflict between the claims of the world and those of the Word. When the magistrate demanded that Bunyan show how it could be lawful to preach, confident that the law against unlicensed preaching left no room for doubt on the subject, Bunyan responded by quoting Peter: "As every man hath received the gift, so let him minister the same." 13 They might as well have spoken two different languages, so fundamentally opposed were their ways of ordering their lives. Bunyan went to jail, for a period that stretched to twelve years, because he could no more stop preaching than he could renounce the Word. To be a "servant in the Gospel," as Bunyan signed himself, meant to act upon it.

The Vanity Fair episode constitutes the most important statement of the warfare between spirit and flesh in The Pilgrim's Progress. By reducing secular society to a fair, Bunyan could imply that the collective opinion and power of "all the men in the world" are devoted to upholding the economic (and class) system upon which their material well-being is founded. In Bunyan's severe view even family relationships have a commercial aspect (his catalogue of merchandise includes "Wives, Husbands, Children"), and the end of all human activity, limited by the perspective of the world, is vanity. At his trial Faithful charges that Christianity and the values of the 
town are "Diametrically opposite." Bunyan heightened the contrast by exaggerating the strangeness of the pilgrims, showing them to be peculiar in dress, in speech, and in their complete indifference to the wares pressed upon them; to the townspeople they are "fools," "Bedlams," "Outlandishmen." As strangers and pilgrims on the earth, seeking a better country, Christian and Faithful simply have no interest in the town; they "buy" the truth, which is to be found only in the Word. Although the justice of the burghers is a cruel farce, they act upon the correct assumption that Faithful's attitude threatens the very basis of their existence. The whole episode illustrates the necessity of choosing between two modes of life that are irreconcilable, between "carnal sense" and "things to come," to use the distinction made for Christian by Interpreter.

All the assumptions about the end of human activity that underlie Vanity Fair, and the indulgence of "fleshly appetite" that they allow, can be comprehended in the term "carnal sense" (or a comparable one, "carnal temper," which Evangelist applies to Worldly Wiseman). One can see a similar repudiation of carnality in Christian's rejection of the appeal of Worldly Wiseman, whose patronizing line finally depends upon the assumption that Christian will be attracted by the prospect of a comfortable, secure existence in the Village of Morality. He offers an ordered society based on a respect for law and class distinctions (to accept his gentlemanly authority and that of Legality would be for Christian to admit that he is one of the "weak" who meddle with "things too high for them").

Vanity Fair strongly suggests actual fair towns of Bunyan's day, and, with the Village of Morality and the City from which Christian sets out, it embodies the material attractions of the real world which Christian must put behind him if he is to attain his goal. These places must be distinguished from landscapes that reflect Christian's inner struggles. Although the Village of Morality and the Slough of Despond can both be located along the "way" that Christian travels, they reflect different orders of experience. The same can be said of the Valley of Humiliation and Vanity Fair. The latter presents the sort of external challenge that the warfaring Christian continually meets in society, and can resist successfully if he only remembers the scriptural language, typically riddling, that enables him to see his life in a heavenly rather than an earthly perspective. To pass through the Valley of Humiliation and other landscapes that dramatize the crises of his inner life Christian must depend upon the action of grace to reveal how the Word will save him. These landscapes appear more perilous because of his uncertainty. 
Bunyan's spiritual landscapes have a fluidity that recalls the shifting terrain of The Faerie Queene. They are often surreal, more like what one might expect in a dream than the actual landscapes one might encounter in Bedfordshire or anywhere else. ${ }^{14}$ The experience of the pilgrim (either Formal or Hypocrisy) who follows the way of Destruction "into a wide field full of dark Mountains, where he stumbled and fell, and rose no more" (p. 42) suggests the abrupt transitions of dreams. One cannot really explain these strange "dark Mountains," even by appealing to Bunyan's source in Jeremiah, except to say that the episode provides a commentary on the nature of spiritual blindness. Dangers rise up unpredictably, and one cannot cope with them by native wit.

The spiritual world that Christian enters in setting out for the New Jerusalem resembles the country he knows yet surprises him in strange ways. The Slough of Despond was obviously inspired by the conditions of Bedfordshire roads (and has been taken as an instance of Bunyan's realism), yet this Slough quickly assumes alarming proportions. Pliable cries out "where are you now?" (p.14) as Christian begins to sink and flees, unable to tolerate a hazard that refuses to conform to the limits of his experience. Pliable is the epitome of the practical man, the sort who has to know exactly where he is going and how, and he cannot follow Christian into the treacherous spiritual landscape that he has entered. Christian himself quickly learns that he is helpless without the Word in this world; only by recognizing the "steps" it provides, with the aid of Help, can he get through the Slough.

The Valley of Humiliation, the Valley of the Shadow of Death, the Delectable Mountains, and the other landscapes that Christian must traverse define a world that is open only to those who believe in the Word sufficiently to seek the goal that he does. These landscapes do not exist for Pliable, who refuses to enter the spiritual country to which they belong, or for Atheist, who cannot find it. The topography of this country is determined largely by Bunyan's experience of Scripture, and the key to Christian's progress through it is his understanding of the power of the Word.

Christian's near disaster in his struggle with Apollyon suggests that this understanding does not come easily. The education in the Gospel that he

14. Henri Talon has commented on the dreamlike quality of Bunyan's landscapes. He describes the country through which Christian travels as a "dream land," a "country of the soul," which becomes "real" for Christian. See "Space and the Hero in The Pilgrim's Progress," Etudes Anglaises 14 (1961), 124-30. The article constitutes part of the introduction to Talon's anthology of Bunyan's works, God's Knotty Log (New York, 1961). 
has received from Evangelist, Interpreter, and the inhabitants of House Beautiful prepares him to resist Apollyon's arguments successfully. ${ }^{15}$ Yet his failure in the physical combat that follows suggests that Christian is deficient in faith and needs the intervention of the Spirit-whose help Bunyan felt all Christians required to understand the implications of Scripture, and even to pray successfully - to be able to manage his sword ("the sword of the Spirit, which is the Word of God" [Eph. 6.17]). The verse that Bunyan chose to signal Christian's new grasp of the power of the Word is particularly suggestive: "Rejoyce not against me, O mine Enemy! when I fall, I shall arise." It points to the paradoxical nature of Biblical truth (a. difficult lesson for Christian to learn) and thus to his own providential recovery, and also, typologically, to Christ's resurrection and his ultimate victory over Satan (Bunyan would have regarded the verse from Micah as foreshadowing these truths).

Christian's cncounter with Apollyon has meaning only for one who grants the fundamental truth of Scripture (Atheist would not conceive of evil in this way). The indefiniteness of the landscape in which Christian meets him can be explained by his spiritual condition and his sense of Scripture at this point. In his guilt and fear Christian imagines the power of the demonic forces that oppose God to be greater than it is. It is startling to discover in reading Part II that the Valley of Humiliation is "fat Ground"; Great-heart tells Christiana, "Behold, how green this Valley is, also how beautified with Lilies" (p. 237). At a comparable stage in his journey Christian lacks the steady spiritual vision that Christiana demonstrates here; he can see only Apollyon coming "over the field" and then straddling the way. Thus preoccupied with the monstrous appearance of evil, he cannot experience the foretaste of Canaan that his more tranquil, and humble, wife does.

Christian defeats Apollyon by discovering how to use the power over evil inherent in the Word. He conquers the darkness and terrors of the Valley of the Shadow of Death by learning to rely upon the illumination of the Word, which enables him to keep to the path. Bunyan associated the darkness and the confusion of this second Valley with a loss of the sense of God's presence. Like Milton's hell, it offers a desolate, sterile landscape ("A Wilderness, a Land of desarts, and of Pits, a Land of drought, and of the shadow of death"), and in this "very solitary place" Christian experiences a

15. Both Kaufmann and Roland Mushat Frye have commented on Christian's education in scriptural truth. In God, Man, and Satan (Princeton, 1960) Frye argues: "Throughout, there is a decpening of understanding on Christian's part, a vitally progressive revelation" (p. 138). 
terrifying feeling of aloneness. In one of the passages that inspired the episode Job in his helplessness sees himself as going to the "land of gloom and deep darkness, the land of chaos, where light is as darkness" (Job 10.22). Bunyan saw that the terror of this "deep darkness" lay in a loss of the confidence and the sense of order that assurance of the comfort of the Spirit affords. Yet Christian's dilemma is finally simpler than Job's, for he can get through the darkness through prayer and a reassertion of faith ("I will walk in the strength of the Lord God"). His ability to believe in the light of the Gospel, unlike the man in the Iron Cage of Despair who has "sinned against the light of the Word" and so grieved the Spirit that "he is gone" (p. 34), causes the light and the Spirit to return. Again the passages that Bunyan quotes point to the paradoxical nature of Biblical truth: "He hath turned the shadow of death into the morning" (Amos 5.8); "He discovereth deep things out of darkness, and bringeth out to light the shadow of death" (Job 12.22). As in the previous episode Christian's experience adds a new dimension to his understanding, and the reader's, of the power of God to bring forth good out of apparent evil.

In retrospect one can see that Bunyan's use of passages from Job to establish Christian's "dark and dismal state" implies his release from that state, for other passages from the book describe the way God enables one to conquer the darkness. One can find a similar implication in Bunyan's use of Jeremiah at the very beginning of the episode. The lines that he draws upon come from God's reproach of the Israelites for forgetting their prior deliverance: "Neither said they, Where is the Lord that brought us up out of the land of Egypt, that led us through the wilderness, through a land of deserts and pits, through a land of drought, and of the shadow of death, through a land that no man passed through, and where no man dwelt? And I brought you into a plentiful country, to eat the fruit thereof and the goodness thereof ..." (Jeremiah 2.6-7). Christian is not deterred by the two men who warn him of the dangers of the Valley ("Children of them that brought up an evil report of the good Land," that is, the spies of Numbers 13), because they in fact confirm that "this is [the] way to the desired Haven" (Bunyan cites Jeremiah 2.6 again at this point). In other words, Christian can go forward because the Valley makes sense to him in terms of the larger pattern of the journey; he understands that the "plentiful country" lies beyond it. Although Christian's confidence is eclipsed temporarily once he is in the Valley, Bunyan's readers would have taken the references to the Exodus as an earnest of his, and their, ultimate deliverance. And they would have seen the whole episode-showing Christian's progress 
through the wilderness, and from darkness to light-as a miniature version of the larger journey.

Thus far I have been concerned with the ways in which Christian, having entered the "Gospel-day," uses the Word as a means to spiritual survival. It is just as important to consider how the Word sustains him by offering consolation, in the form of anticipations of the rewards of the "land of promise." The growth of Christian's capacity to perceive the delights of Canaan is the surest index to his spiritual progress. Bunyan characteristically pictures these delights in terms of Old Testament imagery of fertility, or "fatness" (usually drawn from the Psalms, Isaiah, and the Song of Solomon). He shows Christian experiencing a foretaste of these delights as early as his stay in House Beautiful. In that hostel, built "for the relief and security of Pilgrims" (p. 46), Christian is seated at a table "furnished with fat things, and with Wine that was well refined" (p. 52) and subsequently shown the Delectable Mountains that lie ahead in his journey: “... behold at a great distance he saw a most pleasant Mountainous Country, beautified with Woods, Vineyards, Fruits of all sorts; Flowers also, with Springs and Fountains, very delectable to behold. Then he asked the name of the Country, they said it was Immanuels Land: and it is as Common, said they, as this Hill is to, and for all the Pilgrims. And when thou comest there, from thence, thou mayest see to the Gate of the Coelestial City, as the Shepherds that live there will make appear" (p. 55).

Although the senses must be repudiated when one is trying to resist the temptations of this world (hence Christian stops his ears with his fingers and looks to heaven when in Vanity Fair), they do have a proper use: in experiencing, or anticipating, the delights of the world to come. In The Pilgrim's Progress Bunyan could express metaphorically, in terms of Christian's sensuous awareness, those heavenly delights that Puritan writers and preachers exhorted the faithful to work at imagining. ${ }^{16}$ One can trace a progressive awakening of Christian's senses-in the House Beautiful, beside the River of Life, on the Delectable Mountains, and in Beulah-that corresponds to his increasing awareness that he enjoys the favor of God and the growing satisfaction that he derives from this awareness.

The Delectable Mountains constitute a spiritual height attained only by the stalwart ("For but few of them that begin to come hither, do shew their

16. See Kaufmann, pp. $133 \mathrm{ff}$, for a discussion of the "heavenly-mindedness" of much Puritan meditation and the use of the senses in evoking the joys of heaven. William Madsen, in From Shadowy Types to Truth (New Haven, 1968), pp. 166ff., argues that critics have neglected the imagistic, and sensuous, character of much Puritan writing. 
face on these Mountains," say the shepherds [p. 120]) on which Christian and Hopeful anticipate pleasures to be realized more fully in Beulah. The "Gardens, and Orchards, the Vineyards, and Fountains of water" serve as tangible proof of God's marvellous bounty. When Christian reaches Beulah, the gate of the New Jerusalem is "within sight" and he is able to solace himself with the delights of the place: flowers, singing birds, "abundance" of corn and wine, and, not least, the presence of "shining Ones." Christiana and her company stay up all night listening to the bells and trumpets, so "refreshing" is the place. Their chambers are perfumed, and their bodies anointed, with spices that rival those to be found in Milton's Eden. They are able to experience such sensuous pleasure, paradoxically, because they have achieved the "fullness of the Spirit" that Matthew looks forward to earlier in Part II.

In the early stages of his journey Christian moves through an inhospitable terrain, where he must take refuge in a way station such as House Beautiful and where evidences of divine favor are fleeting and mysterious (for example, the hand that appears with leaves from the Tree of Life to heal Christian's wounds when he is in the Valley of Humiliation). By the time Christian and Hopeful have reached the River of Life the landscape itself sustains them; it is an oasis where they may "lie down safely" and enjoy the lifegiving fruit and water of the place. The Delectable Mountains suggest a large region (Immanuel's land) that embodies the promise of salvation, Beulah a whole "country." Bunyan's great talent for expressing the marvellous in simple terms makes these places convincing for the reader. The pilgrims seem to come upon them quite naturally. When Christian and Hopeful arrive at the Delectable Mountains, they lean upon their staves, as might any "weary Pilgrims," and ask their improbable question ("Whose delectable Mountains are these?") with a disarming straightforwardness.

The relationship between Bunyan's pilgrims and these sustaining landscapes can be described as reciprocal. The sequence of landscapes offers increasing evidence of divine grace and simultaneously an increased faith in "the reality of the things of the world to come" 17 that grace makes possible. Beulah is there for Christian, finally, because he wants and believes it to exist. In his allegorizing commentary on Revelation 22:1, The Water of Life, Bunyan interprets the "pure river of water of life" that flows from the

17. In The Strait Gate Bunyan exhorts his readers to "strive for the faith of the Gospel, for the more we believe the Gospel, and the reality of the things of the world to come, with the more stomach shall we labour to possess the blessedness" (Works, I, 369). 
celestial throne as "the Spirit of grace, the Spirit and grace of God." $18 \mathrm{He}$ goes on to say: "All men ... though elect, though purchased by the blood of Christ, are dead, and must be dead, until the Spirit of life from God and his throne shall enter into them; until they shall drink it in by vehement thirst, as the parched ground drinks in the rain." 19 In addition to the River of Life the springs and fountains that Christian encounters in his journey, beginning with the spring at the foot of the hill Difficulty, embody the "Spirit of grace." As Christian drinks these waters, and eats the fruit of the Tree of Life and of the vineyards of Beulah and the Delectable Mountains, he may be said to grow in spiritual strength and vitality. The process that Bunyan dramatizes would be described in the language of Calvinist theology as "vivification," the "quickening of the spirit" that marks the new life of the Christian. 20

Bunyan relied increasingly on Scripture in describing the landscapes at the end of Christian's journey, skillfully fusing the Old Testament and the New. The Delectable Mountains do not correspond exactly to anything in the Bible. Bunyan placed the shepherds who witnessed the Nativity (as described in Luke) in a landscape that is closer to the Old Testament than to any thing else, thereby offering a symbolic confirmation of Isaiah's prophecy about the coming of Immanuel and exploiting, as he does repeatedly, the suggestiveness of the vineyards and fountains of Canaan. Old and New Testaments also blend in Bunyan's account of the River of Life; it is David's River of God as well as the river of Revelation, and the lush meadow surrounding it recalls Old Testament description. Bunyan's most significant effort to reconcile Old and New Testament visions of blessedness comes at the end of The Pilgrim's Progress, in the juxtaposition of Beulah and the New Jerusalem. The two episodes give Christian's journey a double climax. The delights of Beulah suggest the high level of spiritual satisfaction that can be attained by the faithful in this life, but Christian must cross the river (a spiritual Jordan) to reach the true promised land. The Old Testament vision must be completed by that of the New.

The prominence that Bunyan gave Beulah illustrates better than anything else in The Pilgrim's Progress his strong attraction to Old Testament accounts of the fruitfulness and rest to be found in Canaan ${ }^{21}$ and his ability

18. Works, III, 540 .

19. Works, III, 552 .

20. See John Calvin, Institutes of the Ciristian Religion, ed. John T. McNeill (Philadelphia, 1960), I, 595. See also I, 600; II, 1307, 1456.

21. See, for example, Exod. 3.8, 13.5; Lev. 20.24; Num. 14.8; Deut. 8.7-9, 11.8-12; Josh. 1.13-15. 
to see in the saving history of the Israelites the special destiny of the saints in his own time. Bunyan confirms Christian's election in the terms Isaiah used to prophesy the salvation of the "daughter of Zion"; he is, like Israel, "redeemed of the Lord, sought out." Beulah is the antithesis of the Valley of the Shadow of Death for Bunyan, a place where one can rejoice upon entering a new relationship with God, expressed metaphorically as that of bride and bridegroom, and can rest in the assurance of Isaiah's promises: "Thou shalt no more be termed Forsaken; neither shall thy land any more be termed Desolate" (Isa. 62.4). Bunyan would have seen the land as mirroring Christian's righteousness as well as his sense of election; one implies the other. In reaching this point Christian has himself become fruitful, bearing "the fruits of the Spirit, the fruits of righteousness."22

Bunyan's Beulah takes on some of the characteristics of the heaven it borders (the sun shines perpetually, "shining Ones" come and go) and serves as a preparation for the transition to the New Jerusalem. The pilgrims learn to bear what Bunyan, in the language of the Song of Songs, calls the "sickness" of love for the divine and, since they are not yet ready to experience the glory of the New Jerusalem directly, gaze at the city through an "Instrument" designed to protect them from its dazzling brightness. The fact that Christian no longer needs to worry about relaxing his vigilance (Beulah is beyond the Valley of the Shadow and Doubting Castle, Bunyan says) or about keeping to the way (he can wander into the orchards, vineyards, and gardens whose gates open onto the "Highway" because they belong to the King) suggests that his faith is as certain as it can be. This new certainty is anticipated in Christian's definite response to Hopeful's query ('I would know where we are") as they near the end of the Enchanted Ground: "We have not now above two Miles further to go thereon" (p. 151).

In the New Jerusalem the pilgrims will be beyond the need for faith. As Stand-fast puts it in Part II: "I have formerly lived by Hear-say, and Faith, but now I go where I shall live by sight, and shall be with him, in whose Company I delight my self" (p. 311). Bunyan's narrative no longer depends upon the riddling or metaphoric expression of divine truth but uses the descriptive language of Revelation to establish the reality of the heavenly country that Christian had set out to find: "There, said they, is the Mount Sion, the heavenly Jerusalem, the innumerable company of Angels, and the Spirits of Just Men made perfect" (p. 159). "Now just as the Gates were

22. Works, II, 567. The phrase, a composite of Gal. 5.22-23 and Phil. 1.11, appears in Bunyan's claboration of the parable of the fig tree in Luke 13: The Barren Fig Tree, or The Doom and Downfall of the Fruitless Professor. 
opened to let in the men, I looked after them; and behold, the City shone like the Sun, the Streets also were paved with Gold, and in them walked many men, with Crowns on their heads, Palms in their hands, and golden Harps to sing praises withal!" (p. 162). Bunyan has carefully prepared the reader for the imaginative leap to the New Jerusalem by foreshadowing the divine reality in the landscapes that lead up to it, but he must interpret a landscape such as Beulah typologically, as an expression of the promise and the fruits of the salvation of individual Christians. In the New Jerusalem he will see God not by the metaphoric light of the Word but in fact: "In that place you must wear Crowns of Gold and enjoy the perpetual sight and Visions of the Holy One, for there you shall see him as he is.... There your eyes shall be delighted with seeing, and your ears with hearing, the pleasant voice of the mighty One" (p. 159). The Gospel day will give way to the eternal day made possible by the glory of God.

For all his emphasis on the splendor of the New Jerusalem Bunyan tried to accommodate its glories to his readers' understandings. His angels are simply "shining Ones," and they offer the pilgrims what Bunyan describes in The Heavenly Footman, in the process of reassuring readers who think heaven too grand for them, as a "hearty good welcome," helping them up the hill and explaining what they will encounter inside the city. These guides describe an approachable God with whom the pilgrims will be able to "walk and talk" familiarly and ride out in an "equipage" worthy of the occasion. As Christian and Hopeful approach the gate of the city in the friendly company of the angelic trumpeters they hear bells ringing, as they might on a Sunday in Bedfordshire. One could call such a heaven comfortable.

Yet Bunyan shows his pilgrims, "transfigured" by their heavenly garments, entering into a state of bliss and rest that surpasses anything they could have known in the world and justifies all the trials thay have endured there. The holy joy that they experience can be attained only in the presence of God, in the act of praising him. We last see Christian and Hopeful as they blend into the festive chorus of angels and saints singing: "Holy, Holy, Holy, is the Lord" (p. 162). One cannot overemphasize the importance of this final episode to the structure of The Pilgrim's Progress and the experience of its contemporary readers. The emotional intensity of Bunyan's narrative, as it rises to a series of peaks leading up to the moment of Christian's and Hopeful's reception into the New Jerusalem, registers in unmistakable fashion his own estimation of how far his pilgrims have progressed.

Bunyan's rendering of the glory of heaven, and of the preliminary de- 
lights of Beulah, is one of the great triumphs of the Puritan imagination and the ultimate justification of his use of the metaphor of the journey. The climactic episodes of The Pilgrim's Progress bring the reader all the way from the "carnal" world in which the narrative began up to the contemplation of a transcendant world whose reality is validated by the Word. In the terms of Bunyan's narrative one can gain entrance to heaven only by learning to understand the visible world of ordinary experience in the metaphoric terms established by the Word: as an alien, and ultimately insubstantial country through which God's people must journey until they attain the ultimate satisfaction of communion with God. To accept this mode of thought is to see in the Exodus a pattern explaining and assuring the deliverance of the faithful of all times.

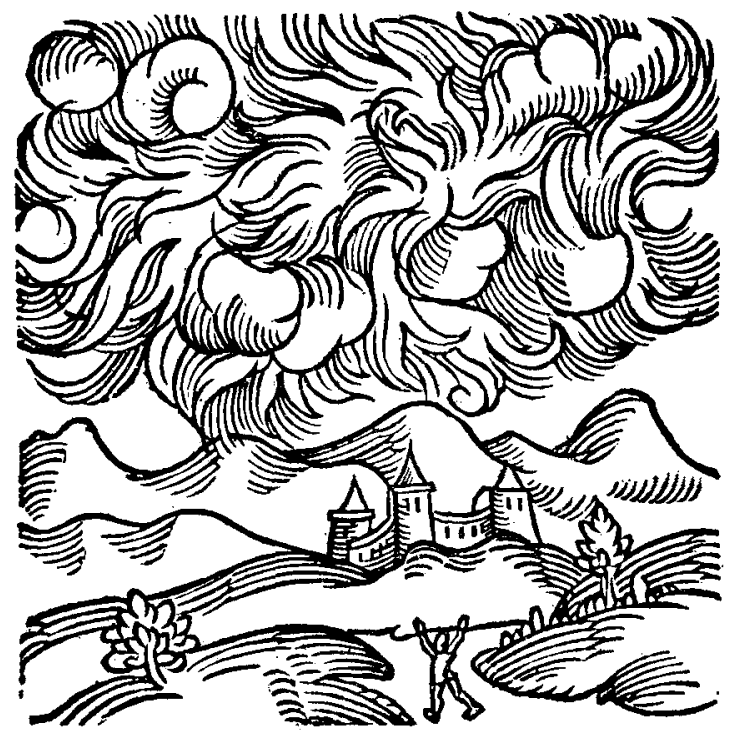

